\title{
The institution of co-operation in border regions - examples of the activities of Polish organisations ${ }^{1}$
}

\begin{abstract}
The aim of this study was to determine the conditions of sustainable (long-term) partnerships for the development of cross-border co-operation with regard to how they are formed and how they function. The analysis concerns partnerships created as a part of the PHARE CBC Small Project Fund between 2000-2003. It focuses on the sustainability of these partnerships through the prism of their duration and the frequency of actions taken. The conceptual assumption was that cross-border cooperation can be seen as an institution and analysis used the concept of path dependency. Entering into relations of co-operation in a border region in Poland is a behavioural norm, but co-operation is not seen in the light of the benefits of entering into a relationship, that is, not in the light of the direct benefits of co-operation.
\end{abstract}

Keywords

Lasting partnership • cross-border co-operation • path dependency

institution $\cdot$ border region

(C) University of Warsaw - Faculty of Geography and Regional Studies

\author{
Katarzyna Szmigiel-Rawska \\ Department of Local Development and Policy \\ Faculty of Geography and Regional Studies \\ University of Warsaw \\ e-mail:k.szmigiel@uw.edu.p \\ Received: 2 October 2012 \\ Accepted: 25 February 2013
}

Introduction

The article tackles the idea of co-operation of organisations located in border regions and discusses the factors affecting the duration of the relationships of co-operation ventured by some parties. The question investigated in this paper has been the subject of research in the social sciences from the very beginning. So as far as scientific discussion is concerned, there is a broad appeal to the theories of economics and sociology in particular, and to works that combine these two approaches. The article focuses on processes and changes, or forecasting changes, rather than on the analysis of static structures and models, and in this sense the line of thought follows the historical approach applied in economics. Consequently, the discussion in the article refers to the concept of path dependency and new institutionalism.

The aim of the research on which this article is based was to determine the conditions of sustainable (longterm) partnerships for the implementation of cross-border co-operation development with regard to how they are formed and the mechanisms through which they function. This paper attempts to define the institution of cross-

\footnotetext{
${ }^{1}$ More information about this research can be found in a book published in Polish, titled: Szmigiel-Rawska, K \& Dołzbłasz, S 2012, Sustainability of cross-border cooperation. PHARE CBC partnerships development paths, Warsaw: CeDeWu Publishing House. The publication marked the end of a project financed by National Science Centre titled Sustainability of international partnerships established within transboundary co-operation. Katarzyna Szmigiel-Rawska was in charge of the research grant.
}

border $^{2}$ co-operation ${ }^{3}$ and to verify which factors arising from this definition of co-operation determine the way in which it is established and maintained.

While formulating the reasoning for this paper, the author focused on the concept of path dependency. This measure allows linking the analyses presented here with the tradition of institutionalism, so this paper uses the reasoning on factors determining the establishment of cooperation offered in the work of E. Ostrom and her colleagues (Poteete, Janssen, Ostrom 2010) as the broader theoretical context.

2In this article, cross-border co-operation is understood as a relationship of co-operation between administrative regions (located in the political and administrative system at the sub-state level) and organisations located outside of the administrative boundaries of the state in which the region in question is situated. Usually these are relationships with other administrative regions or supra-nation political organisations. More on this topic - Szmigiel 2008

${ }^{3}$ To avoid extensive digressions about the term, in the article cooperation is understood to be one of the methods of coordination of social life - co-operation, competition hierarchy (see: Domański 2005). Activities recognised as co-operation are all of those which do not result from hierarchical dependencies and are not competitive. I am aware of the difficulties resulting from the exclusions from this concept of co-operation, as well as of the relationships arising from the hierarchy of analysis within the administrative systems, but these are not as important when we analyse the difficulty of direct crossborder relations. I am also aware of the views of M. Porter (2006) on the relationship between co-operation and competition. In this research model, the competition factor has been omitted as it is seen as a matter of marginal significance. 
In the theoretical literature, the concept of path dependence is considered to be one of the ways of creating institutions (North 1990, Pierson 2000a) and this is the most important feature of that concept presented here for discussion. According to M. Douglas (1987), an institution is understood to be a method of solving problems arising from bounded rationality. This is a way of thinking which is used in the decision-making process and which allows the process to be accelerated and the transaction costs to be reduced by resigning from the authentication of some information. It works analogously to the use of stereotypes in cognitive processes and may have similar consequences.

This article consists of four parts. The first explains the research procedure which constitutes the framework for the conclusions. In the second part, the author focuses on the description and explanation of the results of empirical research and the third part then proceeds to compare the results of the empirical research with the theoretical concepts used at the beginning of the study to devise the research tools. The fourth part contains a summary which refers to the research question raised at the beginning of the paper.

\section{Methods}

The research methods used in the project, the outcomes of which are described in this paper, were based on model assumptions made by the creators of the path dependency concept to trace the formation of cross-border partnerships in the Polish border regions. In other words, the analytical models of the path dependency concept were used to explain the formation of cross-border co-operation.

The views associated with this approach have been juxtaposed with the shape that cross-border co-operation may take. That shape can be defined in three contexts:

1) within a selected partnership;

2) in relation to the activity of one organisation;

3 ) in relation to the situation in a wider area - in the border area, the macroregion, the country or on the continent.

It can be argued that the existence of the partnership is a confirmation of the existence of co-operation. In other words, the shape of the institution of co-operation is determined by the organisational structure and the function implemented by the partnership ${ }^{4}$. In the theoretical literature, there is no general definition of partnership in co-operation across borders which could be treated as an attempt to define cross-border co-operation institutions. So in this article, a partnership is defined by a document on co-operation signed between two or more organisations situated on different sides of a state border $^{5}$.

\footnotetext{
${ }^{4}$ In this context one ought to also consider the relationship between the actual function conducted by the partnership, its socio-cultural foundations and the co-operation institution. The definition of an institution covers the actual use of a function while partnerships, as formal structures (if we consider them an activity of an organisation of power on territorial units, territorial partnerships will go through a phase of formalisation within the natural process of development - Baldersheim and Stahlberg 1999, Szromnik 2008) may merely be a facade (Szmigiel 2009). Then, of course, it will have some functions, but these do not constitute the structures of co-operation.

${ }^{5}$ This definition is simplified and the above-mentioned documents may be very different in nature. After signing an agreement there may be no actions whatsoever or we may also observe co-operation which, especially in the era of European integration, is carried on informally. The assumption of the formalization of a partnership seems to be justified in the context of the co-operation of organisations, including major public sector organisations whose activities are subject to public scrutiny including political control and whose expenditures must be carefully documented. These factors induce the parties involved to formalise actions undertaken across a border by the organisations examined.
}

With regard to the activities of one organisation we can talk about openness, that is about the process of negotiating decisions with different partners (as an element of broad governance), the integration of external actors into these processes (procedures) and in the case of cross-border co-operation, of actors from outside the managed territorial unit. The study on the openness of the organisation investigates whether a network constructed for the purpose of governance is extended to also include foreign organisations.

The third of the proposed contexts can be called the "proper institutionalisation of cross-border co-operation". This context is highlighted when the method of governance, management, administration described by the openness of the organisation has become common in a particular area.

The study focuses on three Polish border areas which have now become internal borders within the EU and where PHARE $\mathrm{CBC}$ projects have been implemented: the western border with Germany and the southern border with the Czech Republic and with Slovakia ${ }^{6}$ (Figure 1).

The beneficiaries of the program took part in the following research procedures:

- An investigation of documents concerning the PHARE CBC Programme, including compilations and databases on the basis of which the author described the spatial distribution of the beneficiaries of the Programme.

- Internet surveys of the beneficiaries of the PHARE CBC programme since 2000 . It was decided to address only those beneficiaries who implemented projects after 2000 , because we conducted the test on two borders - in the south and west. On the Polish-Slovak border, the PHARE CBC programme has only been implemented since 2000. We intended to identify any spatial differences between these three areas but as many of the organisations from western and southern border regions not only implemented the project in 2000 but it turned out that they had also applied them before (and had thus gained experience before 2000) which impeded comparisons. This is why, for most of the conclusions in this paper, the analysed area was treated as a whole.

The survey was sent to 718 organisations benefiting from the Programme after 2000 . These included both local and regional governments, as well as other organisations (community centres, schools, municipal associations, economic self-government organisations and others);

The survey form consisted of 22 questions and was divided into three main parts. The first concerned partnerships that served to implement a Phare-CBC-financed project. The questions pertained to partner organisations, the moment of entering into co-operation, the moment of beginning a Phare CBC project, the issue of whether the co-operation in question was still in progress, the financing model and the formalisation of co-operation, as well as its frequency.

The second part contained questions that focused on the appraisal of co-operation within Phare CBC. Respondents answered questions about their motives for taking up such a project, the most important benefits, the measures continued after the completion of the project and factors determining successful co-operation. The third part consisted of questions referring to the respondent's views on trans-boundary co-operation in general. These questions concerned the reasons that made cross-border

${ }^{6}$ Initially it was planned to analyse the northern border region (alongside the Baltic Sea coast) and so initially databases included beneficiaries from that area. However, only organisations located near the western border took part in the research (those that could take part in both kinds of programmes) and their answers were influenced by involvement in programmes meant for the western and not the northern border. 


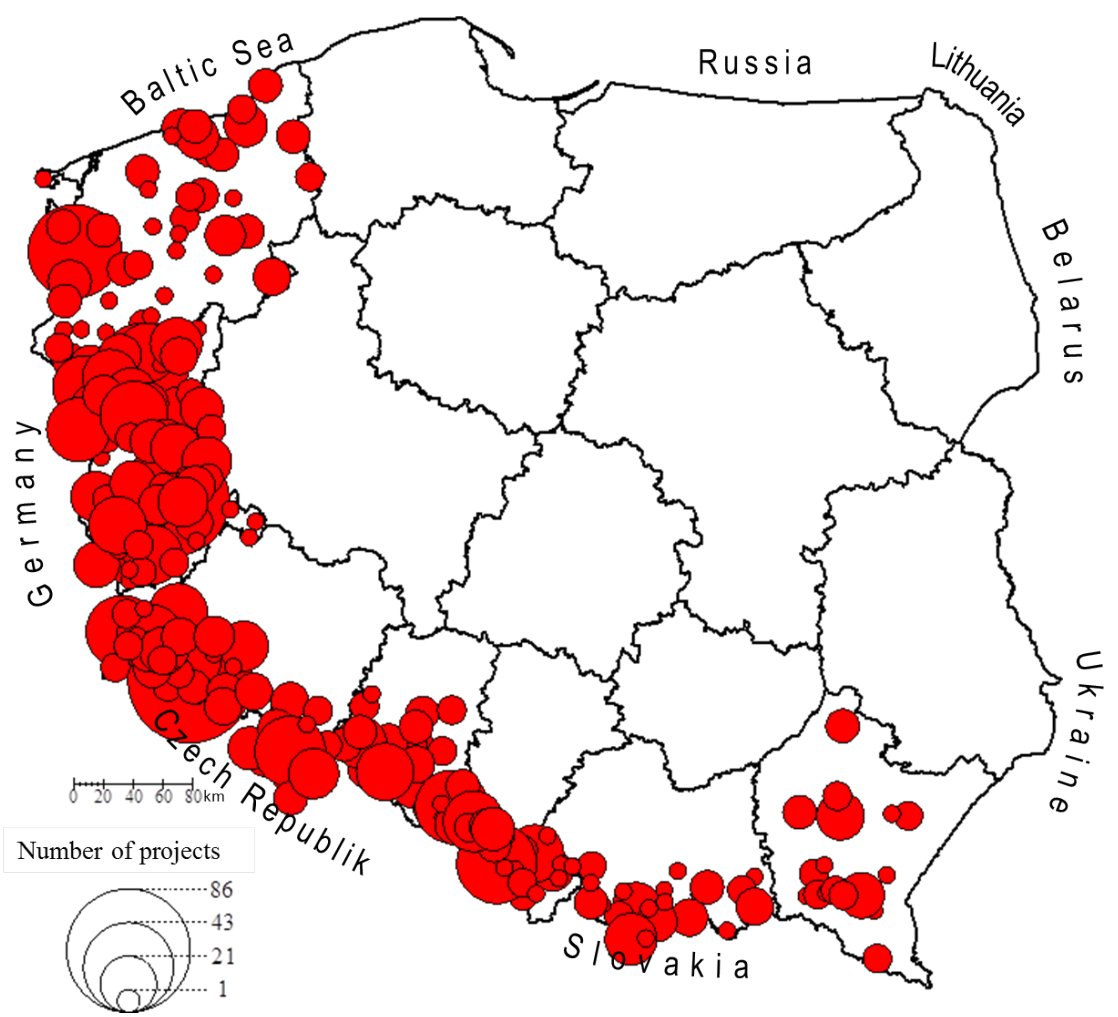

Fig. 1. Distribution of beneficiaries of small Phare CBC programmes between 2000-2003 on the western and southern borders of Poland

Source: Szmigiel-Rawska, K \& Dołzbłasz, S 2012, Sustainability of cross-border cooperation. PHARE CBC partnerships development paths, Warsaw: CeDeWu Publishing House.

co-operation worthwhile, the universality of border region cooperation, reasons for co-operating partners failing to meet their obligations (if that was the case), as well as the diligence of various groups of organisations.

-Analyses of six case studies based on the conditions, causes and effects of the implementation of individual projects -1 on the Polish-Slovak border, 2 on the Polish-German-Czech border and 3 on the northern Polish-German border ${ }^{7}$.

As for the results of the quantitative research, responses were sent in by 48 organisations although only 36 of the respondents had actually completed the survey. The usual reply provided by the respondents was that he or she had been unable to answer the questions. Two reasons were cited most often: either that such projects were not implemented within the organisation, or that the person who had been involved in the project was no longer working for the organisation. The first of those two reasons was clearly untrue - the questionnaire had been sent only to beneficiaries of the Programme and usually the researchers managed to clarify this after an exchange of letters or phone calls. The most symptomatic reply came from one of the respondents: We would love to have helped, but the archives are burned, the people who were in charge of the project are dead and the foreign partner organisation no longer exists. This reply shows the context of research on the sustainability of Polish public organisations, not only in relation to international co-operation (except for the administration organisation).

\footnotetext{
${ }^{7}$ The study was conducted in the first half of 2012. The study consisted of the following organisations: Town and Commune Office of the Muszyna spa resort, the Stronie Śląskie Commune Sport and Recreation Centre, the Kłodzko County Office, the House of Culture in Goleniów, the City of Szczecin and the Pomeranian Dukes' Castle.
}

The survey response rate amounted to $7 \%$. This relatively low figure resulted mainly from the fact that it concerned a period of time dating back ten years. It turned out that some of the organisations that had been Phare CBC beneficiaries back in the early 2000s no longer existed by 2011 (this problem concerned mostly NGOs). The second reason for the low response rate was that respondents were often unable to provide competent answers to the questions, usually as the people originally in charge of the project were no longer employees of the organisation under review. The aim of the questionnaire was firstly, to determine whether partnerships which served purposes of the Phare CBC FMP programme had lasted until the day of the survey and secondly, how the beneficiaries described the frequency of co-operation within a partnership. Furthermore, it also aimed to determine the opinion of respondents on the significance of co-operation, the role of partners, the role of changes affecting cross-border organisations upon entering co-operation relations, the role of motives and benefits that an organisation intending to participate in a project expected to gain, as well as opinions on co-operation in general. The views on co-operation formed a context for the evaluation of what was happening during the implementation of Phare CBC projects.

This was why the case studies, involving in-depth interviews with people in charge of the Phare CBC projects in the period in question and who were still employees of the beneficiary organisation by the time this study took place, were such an important supplement to the research. The case studies also included an analysis of the "history" of development of cooperation between the examined organisations. The goal of this particular analysis was to obtain more detailed data than that collected via the questionnaire. Secondly, it aimed to help identify factors that had determined the continuity of cross-border cooperation as well as the potential coincidences which contributed 
MISCELLANEA GEOGRAPHICA - REGIONAL STUDIES ON DEVELOPMENT

Vol. $17 \cdot$ No. $1 \cdot 2013 \cdot$ pp. 15-24 • ISSN: 2084-6118 - DOI: 10.2478/v10288-012-0031-4

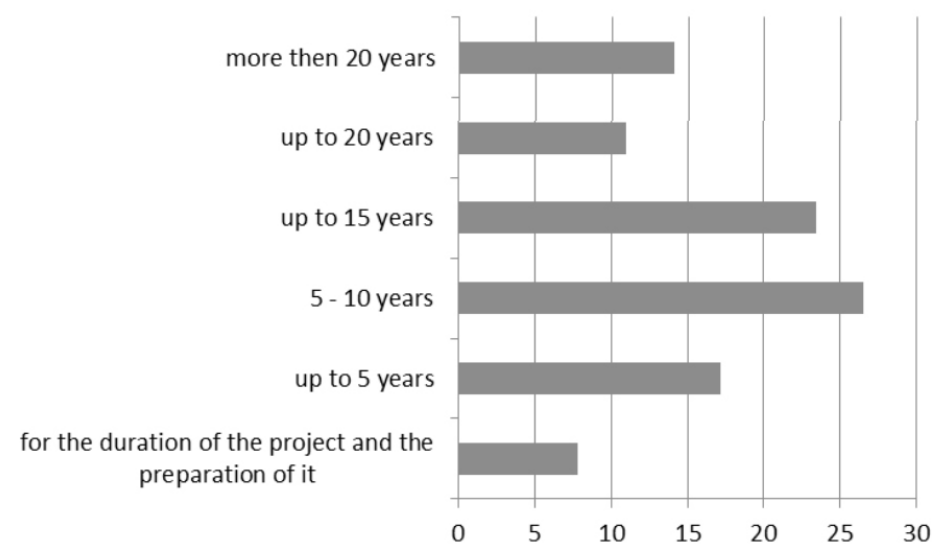

Fig. 2. The duration of cross-border partnerships that provided a framework for the implementation of PHARE CBC projects ( $n=64$, $\%$ of answers)

to the development of co-operation and that would have been difficult to discern otherwise. Attempts were also made to find out the opinions of respondents about the evolution of their cooperation schemes up to that point in time. The individual case studies have not been presented in detail in this study but the conclusions presented in this paper have been nevertheless based on the results of the analysis of documents, survey answers and the summarised results of the case study analysis.

\section{Results of the empirical inquiry}

The PHARE CBC Programme of the European Union was created to finance the development of cross-border co-operation between EU Member State citizens and citizens of the Central European countries that were candidates for joining the European Community. The programme was launched in 1994 and was implemented in Poland until the country's accession to the EU.

The Programme objectives and priorities have changed in subsequent editions. Generally these changes can be summed up by saying that the Programme's first objectives were, above all, concerned with enabling societies to get closer to each other and helping them to overcome the main barriers in making contact in order to establish socio-economic and political relationships. The next set of objectives were concerned with funding the adaptation of border region organisations to the use of the INTERREG III initiative. The most important thematic components (claiming $75 \%$ of the funding) were the fields of transport and environment. Only non-profit organisations were able to benefit from the Programme and at the beginning, these were mostly governmental organisations and organisations connected with local authorities. Non-governmental organisations, universities and other social organisations represented a minority of the entities involved in the PHARE CBC projects. The components of the Programme were implemented in varying constellations, depending on the border region. These border-region constellations can be described as follows: Poland-Germany, Poland-Czech RepublicGermany, Poland-Baltic Sea Region (for the first few years, only Poland-Denmark), Poland-Czech Republic and Poland-Slovakia. In the years between 1994 and 2003, the total amount allocated for this Programme was over 578 million euros (Report closing the implementation of ... 2007)

For public organisations such as local governments located in the border region, PHARE CBC projects were often the first structuralized actions taken up in co-operation with neighbours, or they were associated with the first general experiences of cooperation that took place after the political transformation in 1989. For respondents to the survey, PHARE CBC was a means of learning how to implement cross-border projects. It can be rightly assumed that the implementation of this Programme marks the beginning of cross-border co-operation in the form in which it is conducted today.

\section{Duration of partnerships}

Partnerships implemented by Polish organisations in the border region in which the PHARE CBC projects were implemented have lasted an average of 5 to 15 years (Figure 2) while some have lasted up until this day. By $2011,70 \%$ of partnerships have survived. Analyses conducted by S. Ciok and A. Raczyk also confirmed that the projects implemented under INTERREG IIIA - which was the successor of PHARE CBC, ie a programme designed to finance cross-border cooperation - are implemented by organizations that gained experience during PHARE CBC projects (Ciok, Raczyk 2008). It has to be noted that the set is very diverse - about $14 \%$ of the declared partnerships have lasted for over 20 years, while fewer than $8 \%$ lasted only as long as it took to implement the project, including the preparation period (the entire set numbers 64 partnerships). Of course, among those that are still on-going, the youngest has been in existence for seven years, which means it started in 2004 (the survey was conducted in 2011). One of the most interesting points is that according to the beneficiaries' declarations, some $31 \%$ of the partnerships that constituted a framework for implemented projects have not survived to this day. Most of the partnerships lasted for 5 years - thus it can be inferred that the respondents' answers were politically correct insofar as that by the European Commission's standards, the sustainability of projects should be no longer than 5 years. This conclusion must also mention two facts. Firstly, some of the organisations that filled in the questionnaire refused to answer certain questions because their co-operation had ended. Secondly it was impossible to find some of the organisations. These reservations mean that the set should be considered to be undervalued.

From the information gathered in the survey it can be deduced how many of the partnerships were established directly for the purposes of the Programme. It was assumed that these included partnerships established at the same time as the project started, as well as those that had been established a year before the start. Some $45 \%$ of the partnerships, i.e. nearly half of those that created the basis for a PHARE CBC project, meet the stipulated criteria so it can be concluded that the Programme was an important tool that stimulated the activity of Polish organisations to start cross-border relations. Furthermore, more than half of these partnerships have survived to this day which shows that the programme had potential which not only allowed existing relationships to be developed, but also allowed 


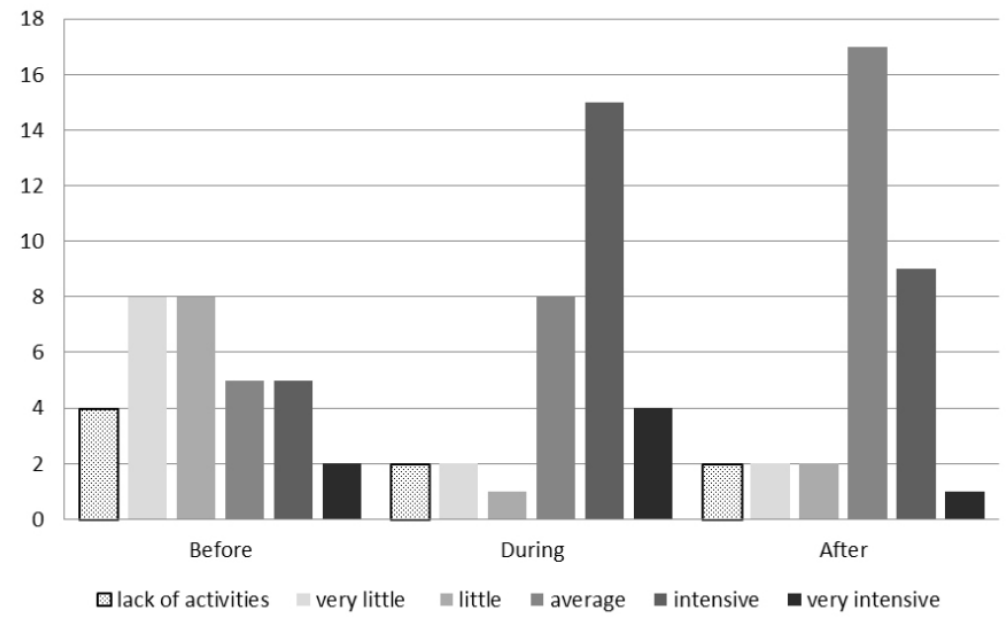

Fig. 3. Number of replies to the question about the frequency of contacts between partners involved in the PHARE CBC project (set= 64 partnerships, number of indications "before" and "during" $n=32$, "after" $n=33$ )

entirely new sustainable partnerships to be created. It acted as an incubator of new partnerships and in a broad sense, it was a tool that allowed the costs of co-operation to be covered (cf. Jałowiecki 2004).

On the other hand, estimates should be very cautious - the researcher has identified two major sets at the each end of the axis. At one end we have a large group of partnerships which are said to have been created and maintained until today as a result of the Programme, while at the other end there is another group, twice as big as the first, of partnerships that did not survive the test of time even though they constituted the framework for a PHARE CBC project.

\section{Openness to co-operation}

Two measures of openness to co-operation were adopted for the purpose of this research. Firstly, it was concluded that an increase in the frequency of contacts occurring within the partnerships selected for this study would be interpreted as a growth of openness to co-operation. The second indicator was tied to the establishment of other partnerships later on and the maintenance of operations within their framework, as well as to the creation of successive cross-border projects. At the same time, the author attempted to identify connections between the initiatives taken up as a result of participating in the PHARE CBC Programme and in subsequent actions. The author will illustrate conclusions using the example of the community office of the Muszyna spa resort.

The respondents provided answers to the question about the frequency of contacts only for 33 partnerships, which represent $2.5 \%$ of all projects undertaken after 2000 . This number is too small to allow any far-reaching conclusions to be made and therefore efforts were taken to verify the assembled data during the case studies.

With regard to the analysis of the frequency of co-operation across border regions in relation to the concept of path dependency, one would expect a gradual increase in the number of contacts between organisations. In this sense however, the results presented here do not fit the assumptions of the concept (Figure 3). However, if they are analysed in relation to particular partnerships - that is in line with the methodology of the project we can assume that an incubation period contributes to a higher frequency of contacts, as it is a period of determining the shape of joint actions and solidifying the structures and habits. Then we encounter a sort of stability. In this context we can note that the negative verification of the assumption, according to which one expected a gradual growth of the frequency of contacts in line with the development of co-operation, may have also been caused by an external initiation of the path. This leads to the pressurising of institutions that want to utilize an external opportunity, so they take actions that do not necessarily result from the evolutionary development of the structure. Thus they reorganize their current path of development and a period of intense activity is followed by a period of stabilisation.

An analysis of the relationship of the Muszyna spa resort shows that the answer to the question about the frequency of co-operation initiated under the PHARE CBC should be complemented by data on activities undertaken in the subsequent partnerships established with other partners.

Formalisation of co-operation launched by informal contacts in 1997, after the agreement on small border traffic was signed by the Polish government, began due to the desire to use external funding, which was seen more as an additional means for the modernisation of the community than as a means to co-operate. After the first successful experiences with the use of these funds, i.e. once local government officers and politicians learned how to use this instrument, the decision to re-engage in this type of initiative became easier. Interestingly enough, the choice of a partner was not a key issue and the partnership was treated rather instrumentally. We can talk about building openness to engage in such activities in the absence of institutional stability of established partnerships.

Factors keeping the development of the co-operation on the path: costs and benefits

According to the concept of path dependence, costs are a relevant factor in the analysis. In the case of co-operation in addition to the financial costs, the organisational, political as well as social costs are also important. In the case of cross-border co-operation, the issue of financing has a specific character and $65 \%$ of the surveyed organisations responded that it paid to make cross-border co-operation as it was a means to raise funds for development. At the same time, respondents answered that cross-border co-operation was expensive in the context of the other costs of running their organisations, so contacts with organisations located nearby were seen as easier. What is more, organisations declared that their co-operation would have been more limited and would have focused mainly on small soft projects if external financing had not been available. 
MISCELLANEA GEOGRAPHICA - REGIONAL STUDIES ON DEVELOPMENT

Vol. 17 • No. 1 • 2013 • pp. 15-24 • ISSN: 2084-6118 - DOI: 10.2478/v10288-012-0031-4

close rapport with representatives of the partner

credibility of the partner

experience of the partner

geographical proximity

reliability

common norms and values

involvement of a significant part of the local communities on both sides

involvement of a large number of employees on both sides

ability to compromise

the same level of economic development

the goodwill of partners

personal relationships with representatives of partner

it is good if the partner is wealthier than us

strong position of the partner in trans-border contacts

we work well when the partner is poorer than we are

foreign representation
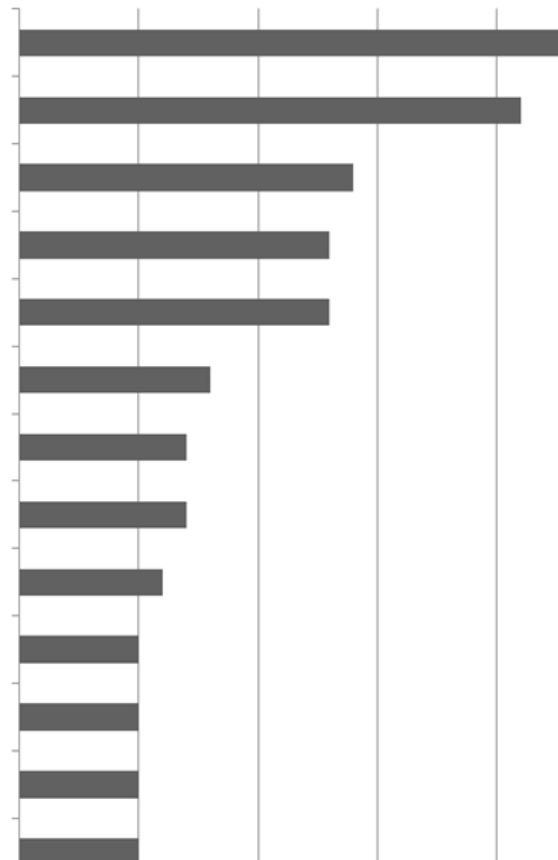

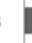

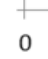

5

$5 \quad 10$

15

25

Fig. 4. The most important factors determining successful co-operation (multiple-choice question, with up to five answers)

Organisational costs relate to the possibility of adapting the organisation to collaboration including the employment of competent persons and the optional transformation of organisational structure. The finding of an adequate, willing partner alone may also be a problem. Factors that generally can be called personal factors - like establishing close rapport with representatives of the partner organisation, the commitment of employees on both sides or the credibility ${ }^{8}$ of the partner - were perceived by the respondents as the most important elements of a successful collaboration (Figure 4).

Political costs are linked to the fact that co-operation may be seen as "bureaucracy tourism" and that spending money on crossborder co-operation is often negatively perceived, especially since measurement of its effects are difficult. For these reasons it is easier to continue activities with a partner with whom one has already been involved on earlier occasions, e.g. a successful project or event. An even bigger argument in favour is if the administrative

\footnotetext{
${ }^{8}$ According to Professor Sztompka (2007), credibility is one of the most important elements of the definition of trust. It remains debatable whether the fact that this indication is ranked so high on the list of factors is merely a confirmation of the significance of that characteristic of social relations, or whether it actually indicates some sort of deficiency within these relations. Answers to other questions posed in the survey reveal that border region organisations find the reliability of foreign local authorities better than that of Polish business partners or even of Polish central organisations. On the other hand, the second most commonly named cause for negligence in relationships - in those cases where it occurred - was the low importance of a relationship for the foreign partners, which could affect the assessment of credibility (the most common answer named factors not dependent on the organisation).
}

organisation was able to include other organisations located in the region, or managed to pass on the relationship. In this case, actions taken up by those organisations are presented as a positive effect of the administration activity (cf. Szmigiel 2009). Thus it is more difficult to establish a new co-operation (with another partner), even if the legitimacy of such actions is suggested by strategic diagnoses and action plans created on the basis of those diagnoses.

As has been already mentioned above, most organisations responded to the question of why it pays to cooperate across borders by saying that it paid off in terms of acquiring additional funds for activities. The second most commonly provided reply referred to the desire to acquire knowledge ${ }^{9}$ (Figure 5). Responses related to cognition seem to dominate the list of reasons why it pays to cooperate (excluding financial reasons) ${ }^{10}$. Reasons concerning the willingness to improve the quality of services and to extend the offer of an organisation came in second, while the least frequent answer related to reasons associated with the desire to improve organisational efficiency. These are definitely advantages that facilitate decisions in favour of further activities. However, they are not sufficient to entice the decision maker to take on mutual challenges (for a group of facilitating factors, not supply- or demand-determining factors - cf. Baldersheim, Bucek, Swianiewicz 2002).I n other words they are not factors which could guarantee lock-in. The motive of gaining financial support can

\footnotetext{
${ }^{9}$ These outcomes are also confirmed by the case studies.

${ }^{10}$ This cafeteria and a majority of questions in the survey have been devised on the basis of the pilot study.
} 


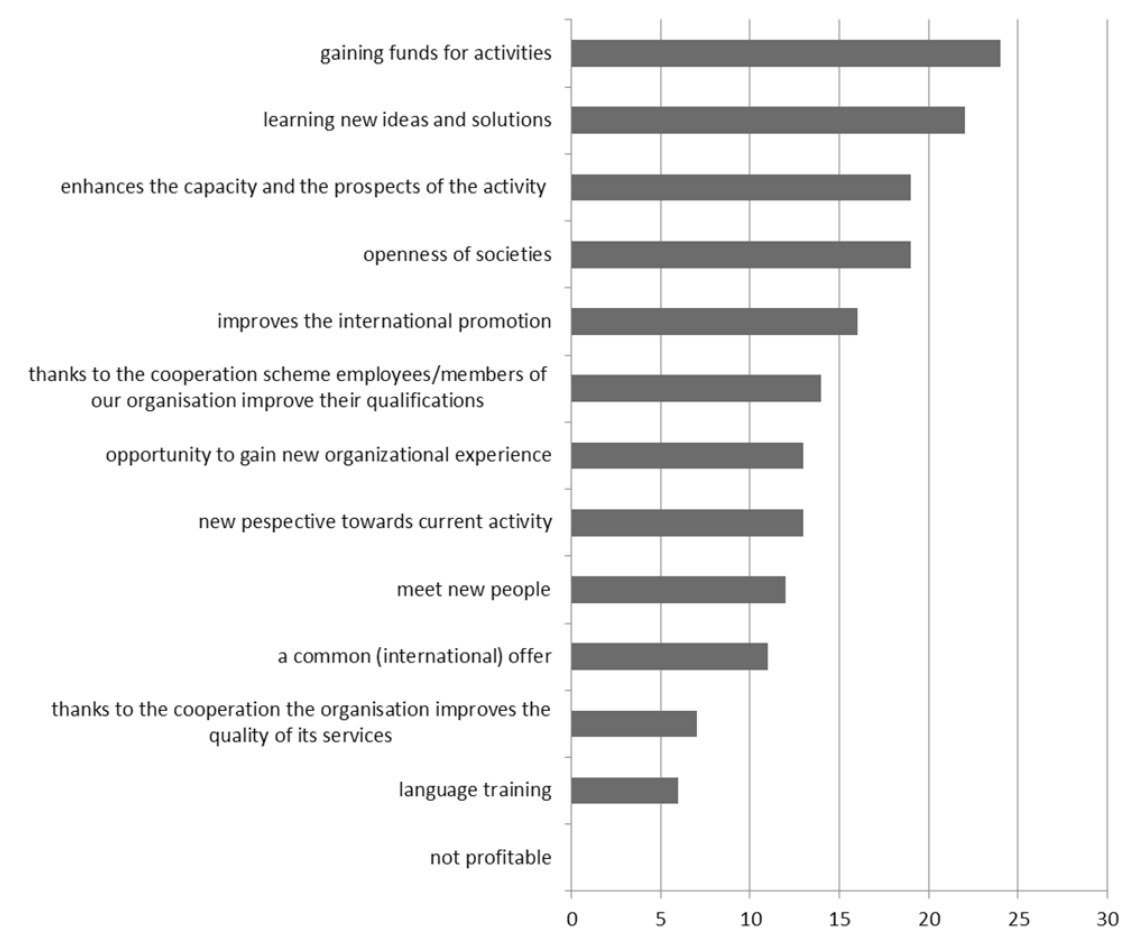

Fig. 5. Reasons for the profitability of cross-border co-operation (multiple-choice question)

be deemed a lock-in factor, although it is also a motive strongly influenced by external factors and as such it cannot vouch for the stability of an institution.

\section{Factors that "weaken the path"}

Research shows that the two most important events that determine changes within cross-border co-operation relationships are personnel changes in the cooperating organisations and the possibility of limitating the availability of external funding. These replies were chosen most frequently, both in the survey as well as during the case studies.

Personnel changes in the organisations analysed can be of two types: in the case of government organisations they can be caused by the political cycle, or they can be associated with personnel changes resulting from staff management decisions in bureaucratic organisations or in other affiliated organisations. The significance of these changes for institutionbuilding stems from the conditions determining the process of learning; an organisation's staff are the source of tacit knowledge which is the most important kind of knowledge used to build a relationship of co-operation. Its importance results from the meaning of credibility for the creation of trust in relationships (cf. Sztompka 2007). Furthermore, according to respondents' answers, what is important in cross-border cooperation is the mutual understanding and desire or positive motivation for entering into relationships - both parties must see their common interest, which is not always obvious, due to the fact that the organisations operate under two separate state systems.

The question of a division into political workers and civil servants is also of significance in organisations exercising power. The argument of continuity is given to support the thesis that it is above all civil servants and not politicians who should be involved in co-operation projects, especially if the co-operation is due to enter the phase of joint projects and if it is not just about learning about communities.
The second factor that might "impair the path" of development of cross-border co-operation concerns significant changes in terms of external financing. Firstly, because the organisations themselves acknowledge that the acquisition of these measures is the most important motive for entering into these relationships. Equally important are organisational changes within the programmes providing funding for activities since they modify the possibility of co-operation with a previously chosen partner and the possibility of continuing activities within particular thematic fields. According to Polish organisations, the introduction of provisions related to the European Territorial Co-operation plan constituted such a turning point. These changes are not universally understood and are often viewed as impediments for joint activities.

PHARE CBC Programme as an instrument that creates a path-dependent process

Generally speaking, a key premise of the path dependency concept tells us that the development of a market or a place depends on the self-sustaining mechanisms that determine the durability of the trajectory of a given development. When the market or place is dominated by a product or model of development as a result of an event, it is difficult to change this situation. The most important prerequisite for creating the concept of path dependence is the conviction that contrary to the views of classical economics, the market seeks not only optimal solutions but also optimal circuits between the seller and the buyer. Optimal solutions means that one achieves the best return for both buyer seller and that the most efficient technologies on the market are implemented (David 1985, North 1990, Arthur 1994).

The discourse in the literature on the concept of path dependency (David 1985, North 1990, Arthur 1994, Anderlini and lanni 1996, Pierson 2000a, Rycroft and Kasch 2002, Araujo and Rezende 2003, Gwosdz 2003) can be summarised by highlighting the key elements that were used to conceptualize this research: 
- historical events that determined the emergence of the "path" - these can be almost completely random, unexpected events that determine further development through coexistence in terms of time, place and actors involved;

- incubation period - this is the time when the shape of a "path" is determined. During this period, accidental conditions can also be important, such as a meeting between two businessmen or skills not appreciated up until that point. Other important factors include time, in accordance with the principle "first come, first served;

- a finite number of potential scenarios (choice set, North 1990) for further development - development depends on the "path" and it is characterised by the fact that some scenarios are more likely than others

- socio-economic environment - in particular the institutional environment in which the processes take place and which may have a more or less significant effect on the trajectory of development and the assessment of effectiveness.

In addition, a reflection on the concept of "path dependency" can be summarised using three notions that determine a relationship:

- sustainability - defines the essence of the concept and highlights the importance of history and choices made in the past for future growth opportunities. This element also allows decisions and events that seem detached from a rational assessment of the circumstances of the organisation to be explained;

- efficiency - effective processes enhance the development trajectory of path-dependence, in other words they maintain growth along a chosen "path". A lack of efficiency is not the decisive factor affecting a change in the "path", nor does it determine the choice of "path" in the first place;

- opportunities - emerging opportunities in the environment weakening the "path" can result in modifications of the chosen "path" or in revolutionary changes to it. The most common, radical change in the external environment only highlights the lack of effectiveness of the system, which was caught up in a lock-in on the "path" and which was previously characterized by higher efficiency. However, as becomes apparent from the theory of games, in a certain situations it might turn into such as an exceptional chance that its use would, in fact, change the balance of power and start a different stage of development.

Can the PHARE CBC Programme be analysed as an instrument for creating a path-dependent process? If we assume after D.C. North (1990) that path dependent processes describe how the institutions emerge and if we make the assumption that an institution of interest to us in these analyses is one of co-operation - then the answer is yes. The PHARE CBC Programme was established in order to induce a multiplier effect in cross-border co-operation in the countries that were to become members of the European Union. It was a tool of "small integration"11.

Thus we accept that, slightly contrary to the assumptions of the theoretical concept, the goal of the PHARE Programme was to induce the creation of stable institutions of cross-border co-operation among organisations located in border regions. This stands in opposition to the assumptions of the theoretical idea, because the concept of path dependency describes an

${ }^{11}$ That is, referring to the functional integration theory it had to elicit integration processes in selected areas which was to result in a multiplier effect in the form of inclusion in the integration process of other areas of social life and of other organisations (cf. Szmigiel 2009). unpredictable process, whereas here it was attempted to provoke such a process "artificially".

The second question related to this issue is whether the path was created. The answer to this question has two facets: one pertaining to the processes in cross-border regions and the other pertaining various partnerships. Creating a contemporary shape of collective action theory, E. Ostrom (2010) distinguishes three groups of key factors influencing the possibility of effective action:

1) cognitive restraints and risk assessment;

2) norms and social interactions;

3) interaction between contextual factors

The border location can be one of the explanations that helps to alleviate the conclusions regarding the condition of institutions of co-operation in general - the neighbouring location of immobile territorial units eases the consequences of a lack of formal links and positive effects on the risk assessment. Also P. Pierson (2000b) refers to cognitive limitations and risk assessment, summarising the reasoning of the creators of the path dependence concept. $\mathrm{He}$ lists the following mechanisms that determine the formation of feedback which lock in the development to a chosen path:

- high initial costs and high fixed costs;

- significant learning outcomes in connection with the operation of complex systems;

- external network effects;

- individual expectations about behavioural norms (adaptive expectations).

It seem that costs are an obvious determinant - organisations see collaboration as an expensive addition. Furthermore, because of the organisational, social and political costs, we can talk about high initial costs of establishing further partnerships. The learning effects are undoubtedly among those most commonly attributed to cross-border co-operation. We consider them in the context of a learning organisation, or the administration of a learning organisation and a learning region. Administration is also a complex system that satisfies the conditions of the second mechanism indicated by Pierson (2000b). On the other hand, this interpretation is not unambiguous. According to the creators of the concept of path dependency, it is mostly a development associated with the introduction of new technologies into the product creation process. Difficulties occur in terms of the replacement of one technology by another, especially if the change is a revolutionary one (for example the difficulties associated with the use of new fuels for the energy or automotive market). In public administration these dependencies are not present, but in order to explain the phenomenon of a lock-in on the path we can use the theory of incremental changes; this is a concept elucidating why it is often the small decisions leading to evolutionary and not revolutionary changes that are chosen by the management of political and bureaucratic organisations. Answering the question of why reforms in the administration are always slow, E. Lindblom (1959) lists six, widely discussed, reasons:

1. Instead of taking a comprehensive study and evaluation of all available alternatives, the decision maker focuses only on those policies that slightly differ (incrementally) from the existing policy;

2. Only a relatively small number of alternative policies is under consideration;

3. For each alternative policy, only a limited number of important consequences is considered;

4. The problem confronting the decision maker is constantly 
being redefined, whereas proceeding on the principle of incremental changes allows for numerous corrections of measures for its solution which makes the problem easier to manage;

5. Therefore, there is no single decision or right solution, but only a "never-ending series of attacks" on the process managed at the time, through a series of analyses and evaluations;

6. This way of the decision-making process is used to repairing, alleviating the current social imperfections rather than promoting the future social goals (Etzioni 1967).

The way public management is treated is strongly correlated with the lock-in of development on the path in the path dependency concept - i.e. the reluctance to make radical changes and an unwillingness to consider alternative ways of development. Among the reasons for such a situation, Lindblom (1979) lists cognitive abilities as well as the costs of gathering information and calculations. Cross-border relations increase both the effort needed to gather information and the cost of this process (although nowadays it is not as obvious as it used to be in the era before the development of telecommunication technologies). We can therefore risk the claim that there is a learning effect mechanism in complex systems of cross-border co-operation, particularly when we consider the administrative units.

Summary - did the processes in border regions lead to the creation of institutions of co-operation?

In the cases analysed, the author has identified several patterns of behaviour applied within the framework of cooperation which we can consider to be a different manifestation of the institution of co-operation, i.e. using the terms established by North DC (1990), the author diagnosed the following choice set:

- partnerships for the purpose of implementing the PHARE $\mathrm{CBC}$ Programme lasted as long as required as per rules of the Programme;

- partnerships established for the PHARE CBC Programme did not last longer than the required period of 5 years; no further actions were established, but the partner organisation is seen as a potential partner in future activities because of the acquired knowledge of administrative and organisational conditions in which the organisation operates and due to its geographical location;

- an institution of partnership was established in which decisions were consulted with the foreign partner, even if that decision concerned a new field which hitherto had not been the subject of the co-operation; the organisations had also clearly defined plans for future co-operation, however these are dependent on external financing;
- the development of the cross-border co-operation policy established the institution of openness to interact with crossborder partners. This openness is subject to two factors: the external financing that is still available and the knowledge that both parties have gained about each other. It is influenced by other effects of existing co-operation to a much lesser extent;

- as the other elements of the cross-border co-operation institution are so diverse, it is difficult to draw conclusions on the influence of integration. The study does not allow the question regarding the universality of the institution of partnership and the institution of openness to be answered.

It seems that in this case, the factors determining the institution of co-operation in border regions are the opportunities for external financing which affect the institution to such an extent that when we talk about the stability of the path, were are led to the conclusion that the cessation of external funding might cause the complete abandonment of certain courses of actions. Although this seems unlikely to cause a complete disappearance of the institution of co-operation, it may nonetheless result in the abandonment of many paths or in the negative impact of a development lock-in of the co-operation on the least efficient paths if such co-operation is considered a convolution of several dozen or several thousand paths (depending on whether we analyse the partnership, openness of the organisation, or field of integration), In other words, Polish local leaders would undertake cross-border co-operation if there was no external financing, but the scale and range of this occurrence will be noticeably smaller, because they are not willing to spend large sums of public money on this activity for both political and calculated reasons - often they do not see common important goals. On the other hand, only the cessation or minimization of external financing allows the question about the actual existence of the institution of cooperation to be answered.

The second group of factors determining the institution of cooperation in a border region is associated with the low level of actual stabilisation in/of Polish organisations in general (formal, organisational, political). The institution building process is an example of long-lasting processes and over the last 25 years, Poland has experienced many, deep organisational, political and legal changes that affect, to a large extent, externally stimulated processes such as cross-border co-operation.

Usually entering into relations of co-operation in a border region is a behavioural norm, but co-operation is not seen in the light of the benefits of entering into a relationship, that is, not in the light of the direct benefits of co-operation. It is seen as a tool for increasing competitiveness only in the context of gaining external funding for development. It is not perceived as a means of building a stable channel for the diffusion of production factors.

\section{References}

Anderlini, L \& lanni, A 1996, 'Path dependence and learning from neighbors', Games and economic behaviour,13, pp. 141-177.

Araujo, L \& Rezende, S 2003, 'Path dependence, MNCs and the internationalization process: a relational approach', International Business Review,12, pp. 719-737.

Arthur, WB 1994, Increasing returns and path dependence in economy, The University of Michigan Press.

Baldersheim, H \& Bucek, J \& Swianiewicz, P. 2002, 'Mayors learning across borders: the international networks of municipalities in East-Central Europe', Regional and Federal Studies, vol. 12, nr 1, s. 126-137.

Baldersheim, H \& Stahlberg, K 1999, Nordic region-building in a European perspective, Ashgate Publishing Ltd, Hants, Vermont.

Ciok, S \& Raczyk, A 2008, 'Implementation of the EU Community Initiative INTERREG III A at the Polish-German border. An attempt at evaluation, M Leibenath \& $E$ KorcelliOlejniczak \& R Knippschild, Cross-border Governance and Sustainable Spatial Development: Mind the Gaps! Springer.

David, PA 1985, 'Clio and the economics of QWERTY', The American Economic Review, vol. 75, no. 2, pp. 332-337.

Domański, R 2005, Geografia ekonomiczna. Ujęcie dynamiczne, Wydawnictwo Naukowe PWN, Warszawa. 
MISCELLANEA GEOGRAPHICA - REGIONAL STUDIES ON DEVELOPMENT

Vol. 17 • No. 1 • 2013 • pp. 15-24 • ISSN: 2084-6118 • DOI: 10.2478/v10288-012-0031-4

Douglas, M 1987, How institutions think, Routledge, London.

Etzioni, A 1967, 'Mixed-Scanning: A "Third" Approach to Decision-Making', Public Administration Review, 27. 5, pp. 385-392.

Gwosdz, K 2003, ‘Pozytywne i negatywne ścieżki (virtuous and vicious paths) - próba zastosowania teorii zależności od ścieżki (path dependency) do wybranych miast konurbacji górnośląskiej' in Wymiar i współczesne interpretacje regionu, eds I.Sagan\& M. Czepczyński, Gdańsk - Poznań, pp. 227238.

Jałowiecki, B. 2004, 'Program w opinii gmin, instytucji i mieszkańców' in: G. Gorzelak, J. Bachtler, M. Kasprzyk (ed.), Współpraca transgraniczna Unii Europejskiej. Doświadczenia polsko-niemieckie, Wydawnictwo Naukowe Scholar, Warszawa.

Lindblom, ChE 1959, 'The Science of „Muddling Through”, Public Administration Review, 19.2, pp. 79-88.

Lindblom, ChE 1979, 'Still Muddling, Not Yet Through', Public Administration Review, 39.6, pp. 517-526.

North, D C 1990, Institutions, institutional change and economic performance. Political Economy of Institutions and Decisions, Cambridge University Press.

Pierson, P 2000a, 'Increasing returns, path dependence, and the study of politics', The American political science review, 94.2, pp. 251-267.

Pierson, P 2000b, 'The Limits of Design: Institutional Origins and Change', Governance: An International Journal of Policy and Administration, 13.2, pp. 475 - 499.

Porter, ME 2006, Przewaga konkurencyjna. Osiąganie $i$ utrzymywanie lepszych wyników, Wydawnictwo Helion, Gliwice.
Poteete, AR\& Janssen MA \&Ostrom E 2010, Working together. Collective action, the commons, and multiple methods in practice, Princeton University Press, Princeton and Oxford.

Raport zamykający wdrażanie Programów Współpracy Przygranicznej, Sprawiedliwości i Spraw Wewnętrznych oraz Spójności Społeczno-Gospodarczej Phare realizowanych przez Władzę Wdrażającą Program Współpracy Przygranicznej Phare / Władzę Wdrażającą Programy Europejskie [Report concluding the implementation of Phare Programmes for Cross-Border Co-opperation, Justice and Internal Affairs and Social and Economic Cohesion, Carried Out by the Implementing Authority for the Cross-Border Cooperation Programme Phare /Implementing Authority for European Programmes],, 2007, Zespół Ewaluacji i Promocji, Warszawa: Władza Wdrażająca Programy Europejskie.

Rycroft, RW\& Kasch, DE 2002, 'Path Dependence in the innovation of complex technologies', Technology Analysis \& Strategic Management, Vol. 14, nr. 1, pp. 21-35.

Szmigiel, K 2008, 'Relacje, konkurencja, współpraca. Próby znalezienia właściwych definicji dla działań podejmowanych na arenie międzynarodowej przez regiony administracyjne' in: Przekształcenia regionalnych struktur funkcjonalnoprzestrzennych. "Europa bez granic", Instytut Geografii i Rozwoju Regionalnego Uniwersytetu Wrocławskiego, Wrocław.

Szmigiel, K 2009, Regionalne po co i z kim? Internacjonalizacja relacji polskich województw, GEOPROFIT, Warszawa.

Szromnik, A 2008, Marketing terytorialny, Wolters Kluwer, Warszawa.

Sztompka, P 2007, Zaufanie. Fundament społeczeństwa, Wydawnictwo ZNAK, Kraków. 